\title{
Mass Spectrometry and Structural Biology Techniques in the Studies on the Coronavirus-Receptor Interaction
}

\author{
Danuta Witkowska \\ Institute of Health Sciences, Opole University, Katowicka 68, 45-060 Opole, Poland; \\ danuta.witkowska@uni.opole.pl \\ Academic Editor: Derek J. McPhee \\ Received: 1 August 2020; Accepted: 9 September 2020; Published: 10 September 2020
}

\begin{abstract}
Mass spectrometry and some other biophysical methods, have made substantial contributions to the studies on severe acute respiratory syndrome coronavirus 2 (SARS-CoV-2) and human proteins interactions. The most interesting feature of SARS-CoV-2 seems to be the structure of its spike (S) protein and its interaction with the human cell receptor. Mass spectrometry of spike $S$ protein revealed how the glycoforms are distributed across the $S$ protein surface. X-ray crystallography and cryo-electron microscopy made huge impact on the studies on the S protein and ACE2 receptor protein interaction, by elucidating the three-dimensional structures of these proteins and their conformational changes. The findings of the most recent studies in the scope of SARS-CoV-2-Human protein-protein interactions are described here.
\end{abstract}

Keywords: spike protein-ACE2 interaction; MS; structural techniques; glycosylation; SARS coronavirus

\section{Introduction}

Emerging infectious diseases caused by severe acute respiratory syndrome coronaviruses (SARS-CoV and SARS-CoV-2) present a tremendous threat to international public health [1]. The risk to the global population brought by the Middle East respiratory syndrome (MERS-CoV) [2] is deemed to be much lower. According to the World Health Organization (WHO), the fatality rate of MERS-CoV is quite high $(36 \%)$ [3,4]; however, the virus does not seem to pass easily from person to person. Dromedary exposure has been shown to be one of the main risk factors for that disease [3,5,6]. The other four coronaviruses that are pathogenic to humans (229E, OC43, NL63, HKU1) are usually associated with mild clinical symptoms [4,7].

According to the International Committee on Taxonomy of Viruses, coronaviruses belong to the subfamily Coronavirinae in the family Coronaviridae [8]. The group of viruses was recognized by a few virologists in 1968 [9]. The viruses were named "coronaviruses" to reflect the characteristic crown-like appearance by which they are identified under an electron microscope (EM) [9]. Coronaviruses are enveloped, positive-sense, single-stranded RNA viruses of pleomorphic shape, measuring between 80 and $160 \mathrm{~nm}[1,10]$. On the basis of serological and genomic evidence, CoVs are categorized into four important genera: Alphacoronavirus, Betacoronavirus, Gammacoronavirus, and Deltacoronavirus [1].

Betacoronaviruses have been found mainly in bats [11], camels [12,13], rodents [14] and rabbits [15]. During the past two decades, three known betacoronaviruses have caused epidemics in humans: SARS-CoV, MERS-CoV and SARS-CoV-2 [16]. The SARS-CoV outbreak during 2002-2003 involved 8422 patients and spread to 29 countries globally [17]. A total of 813 fatalities were attributed to that SARS epidemic [1]. Ten years later, MERS-CoV broke out in Saudi Arabia, and later in South Korea, affecting more than 2000 people [18,19].

In December 2019, a few adult patients with pneumonia of unknown cause were admitted to a hospital in Wuhan [20]. In early January 2020, a novel betacoronavirus (SARS-CoV-2, tentatively 
named 2019-nCoV) was identified from the throat swab sample of a pneumonia patient in Wuhan, followed by many other cases [21-23]. The illness caused by SARS-CoV-2 has been officially named Coronavirus Disease 2019 (COVID-19) by the WHO [24,25]. The number of COVID-19 cases has been rising dramatically all over the world, especially in the United States, with the highest rates of death among the elderly and people with comorbidities [26]. The reason for its high infectivity can be found in the unique features of its structural proteins [27] and the capacity of SARS-CoV-2 to be transmitted by asymptomatic people [28,29]. Asymptomatic cases have been mainly reported for infants and children [22,30]. Nonetheless, respiratory droplets are the main route of transmission [7]. Early symptoms in most COVID-19 patients include fever, cough, dyspnea, myalgia, and sore throat $[21,31]$. A basic reproductive number $\left(\mathrm{R}_{0}\right.$-the expected number of cases directly generated by one case) of SARS-CoV-2 has been determined to range from 2 to 3 [32,33]. However, some studies using mathematical methods estimate the $\mathrm{R}_{0}$ of COVID-19 to be as high as 6.49 [34].

This review is focused on the interactions of betacoronaviruses ( $(\mathrm{B}-\mathrm{CoV})$ with human proteins, with the emphasis on SARS-CoV-2 and its spike (S) structural protein. The importance of mass spectrometry (MS) methods and other instrumental techniques in these studies, which can lead to the results supporting preclinical and clinical studies, has been stressed.

\section{Differences and Similarities between SARS-CoV and SARS-CoV-2}

At present, COVID-19 exhibits less mortality than SARS and MERS; however, it shows much stronger infectivity [35], most likely due to its notable genomic features [27].

In January 2020, Lu et al. revealed $99.98 \%$ sequence identity of the viral genomes obtained from patients who were early cases of the outbreak in Wuhan, suggesting a single spill-over event from one source within a very short period [23]. Eight of the nine studied cases had contact with the Huanan seafood market in Wuhan. One patient had never visited the market; however, he had stayed in a hotel near the market before the onset of his disease [23].

The newly discovered SARS virus was shown to have a better sequence identity with SARS-CoV than with MERS-CoV [36]. Zhou et al. discovered that SAS-CoV- 2 is $96.2 \%$ identical at the whole-genome level to a horseshoe bat coronavirus [37]. Additionally, the amino acid sequences of the seven conserved replicase domains in open reading frame (ORF) that were used for coronavirus species classification displayed $94.4 \%$ similarity in identity between SARS-CoV-2 and SARS-CoV [37]. This similarity suggests that the two viruses belong to the same species. Consequently, the new coronavirus is thought to be a recombinant virus transmitted from bats to humans by the means of an unknown intermediate host [26]. Some researchers link SARS-CoV-2 to pangolin viruses because of the very high similarity of their receptor-binding domains (RBDs) [38].

The origin of the infection is still under investigation. Two scenarios of the origin of COVID-19 have been proposed: (I) natural selection in viral evolution in an animal host before zoonotic transfer; and (II) natural selection in humans following zoonotic transfer [27]. Some researchers believe that SARS-CoV-2 coronavirus is a recombinant virus between several bat SARS-like betacoronaviruses $[39,40]$.

The RNA genome of coronaviruses is one of the largest among all the RNA viruses. The length of the SARS-CoV genome is 29,727 nucleotides, with 11 open reading frames [41,42].

In CoVs, the proteolytic processing of the $5^{\prime}$ two-thirds of the genome results in the production of 16 nonstructural proteins that are involved in viral RNA replication and transcription [43]. Approximately one-third of the betacoronavirus genome encodes four structural proteins: membrane-spanning spike (S), envelope (E) and membrane (M) proteins and a single nucleocapsid (N) protein $[10,44]$ These structural proteins have been shown to play an important role in the pathogenesis and complications of SARS disease [1]. Additionally, the SARS viruses contain a few accessory proteins. Some betacoronaviruses also encode a hemagglutinin esterase (HE) glycoprotein [45]. However, it was shown that SARS-CoV does not encode the HE protein [46]. Interestingly, there is no significant amino acid sequence similarity between the SARS-CoV accessory proteins and any known viral or cellular 
proteins [47]. Both SARS-CoV and SARS-CoV-2 access their host cells by a process of membrane fusion that is mediated by a homotrimeric "spike" (S) protein [48].

The current knowledge on SARS-CoV-2 is still limited, but every day, new research data become visible. It has been shown that SARS-CoV-2 is distinct from SARS-CoV in the phylogeny of the complete RNA-dependent RNA polymerase (RdRp) gene [23].

The most fundamental difference between the SARS-CoV and SARS-CoV-2 viruses lies in their gene sequences. The amino acid sequence of the virus causing COVID-19 differs from other betacoronaviruses. specifically in the regions of the nucleocapsid $(\mathrm{N})$ protein and the $\mathrm{S}$ glycoprotein, as well as in the $1 \mathrm{ab}$ polyprotein [36]. Among the four structural proteins of SARS coronavirus, the nucleocapsid (N) and the spike (S) have been shown to be the main immunogens [49].

Moreover, experiments with UV-inactivated virus revealed that SARS-CoV S protein induces ER stress, which has a significant impact on cell homoeostasis and may contribute to viral pathogenesis [50]. It is worth mentioning that SARS-CoV-2 S glycoprotein shares $97 \%$ sequence identity with the spike protein of the bat coronavirus RaTG13 [37,51].

Nucleocapsid protein, with a mass of $50 \mathrm{kDa}$, is the most abundant macromolecule in coronaviruses and is highly immunogenic [52]. The comparison of the whole amino acid sequence of chosen $\mathrm{N}$ proteins revealed $87.86 \%$ similarity between SARS-CoV-2 and pangolin CoV, 90\% similarity to SARS-CoV, and $99 \%$ similarity to bat CoV [52]. The nucleocapsid protein of SARS-CoV has the capacity to neutralize the immune response of the host. If the SARS-CoV- $2 \mathrm{~N}$ protein does not share that capacity, this can explain the lower mortality rate than that of the 2003/4 SARS epidemic [53]. The spike glycoproteins of SARS coronaviruses are reviewed in more detail below, as well as the current knowledge about their interactions with the human receptor.

Most relevant similarities and differences between SARS-CoV and SARS-CoV-2 have been summarized in Table 1. It should be noted that the estimation of the $\mathrm{R}_{0}$ and the mortality rate during the epidemic can be plagued by data uncertainty and variability [54].

Table 1. Comparison of the biological features of SARS-CoV and SARS-CoV-2.

\begin{tabular}{cccc}
\hline Characteristic & SARS-CoV & SARS-CoV-2 & References \\
\hline Emergence date & November 2002 & December 2019 & {$[55-57]$} \\
\hline Area of emergence & Guangdong, China & Wuhan, China & {$[55,56,58]$} \\
\hline Key hosts & Bat, palm civets, raccoon dogs & Bat, pangolin & {$[59-61]$} \\
\hline Entry receptor & ACE2 & ACE2 & {$[23,62-64]$} \\
\hline $\mathrm{R}_{0}$ & $2-5$ & $1.5-6.5$ & {$[34]$} \\
\hline Transmission & Droplets, contact with infected \\
people & $\begin{array}{c}\text { Droplets, contact with } \\
\text { infected people, even } \\
\text { asymptomatic }\end{array}$ & {$[28,29,65]$} \\
\hline Mortality rate & 9.6\% & 3-3.6\% & {$[66-68]$} \\
\hline $\begin{array}{c}\text { Symptoms } \\
\text { of disease }\end{array}$ & $\begin{array}{c}\text { Fever, headache, cough, } \\
\text { dyspnea, shivering, myalgia, } \\
\text { malaise and diarrhea }\end{array}$ & $\begin{array}{c}\text { Fever, headache, cough, } \\
\text { myalgia, dyspnea, sore } \\
\text { throat, chills, and loss of } \\
\text { taste or smell, diarrhea }\end{array}$ & {$[21,31,57,69]$} \\
\hline N protein & IFN- $\gamma$ inhibitor & Unknown & {$[35,53]$} \\
\hline
\end{tabular}

Very recently, 332 high-confidence SARS-CoV-2 protein-human protein interactions that are associated with multiple biological processes have been identified using affinity-purification mass spectrometry (AP-MS) [70]. Comparison of the interacting proteins between SARS-CoV-2 and ten other pathogens using a hypergeometric test revealed that West Nile virus and Mycobacterium tuberculosis had the most similar host-protein interaction partners [70]. The novel SARS virus interactome exposes new aspects of SARS-CoV-2 biology and potential targets for SARS-CoV-2 inhibition. 
In another study, MS-based HLA-I (human leukocyte antigens-I) and HLA-II epitope binding prediction tools were utilized to identify SARS-CoV-2 epitopes recognized by helper and cytotoxic $\mathrm{T}$ cells $\left(\mathrm{CD} 4^{+}\right.$and $\mathrm{CD} 8^{+}$, respectively) [71]. Responses to both $\mathrm{CD} 4^{+}$and $\mathrm{CD} 8^{+} \mathrm{T}$ cells have been detected in SARS-CoV and in SARS-CoV-2-infected patients [72,73]. Unlike traditional binding assays which rely on chemical synthesis and the a priori knowledge of ligands to be assayed, MS method used by Poran et al. was based on natural peptide-HLA complexes that are subject to the endogenous processing and presentation pathways within the cell [71]. It has been revealed that the relative expression of SARS-CoV-2 proteins in virally infected cells vary significantly; this should be considered in vaccine design to induce cellular immunity [71].

\section{Spike Glycoproteins}

As the $\mathrm{S}$ protein is surface-exposed and mediates the host cell penetration by coronaviruses, it is the main focus of vaccine and therapeutic design [48,51]. Understanding the role of the SARS viruses spike glycoprotein and the character of its interaction with host receptor is fundamental to the understanding of viral pathogenesis $[74,75]$. One of the hypotheses to explain the higher transmission rate of SARS-CoV-2 compared to SARS-CoV is the genetic recombination of the S protein $[27,48,76]$.

The $S$ protein of SARS coronaviruses belongs to class-I viral fusion proteins. It consists of three monomers, each 1200 amino acid residues long (Figure 1A) [73]. Each monomer of this densely glycosylated spike protein is approximately $180 \mathrm{kDa}$ and contains two subunits, S1 and S2 (Figure 1C), which are responsible for the attachment to the host cell and membrane fusion, respectively $[77,78]$. S2 subunits of SARS-CoV-2 and SARS-CoV are structurally conserved, whereas the $\mathrm{S}$ binding part of SARS-CoV, which is used to recognize its entry receptor, shares only approximately $73-75 \%$ overall amino acid sequence identity with SARS-CoV-2 binding domain [79].

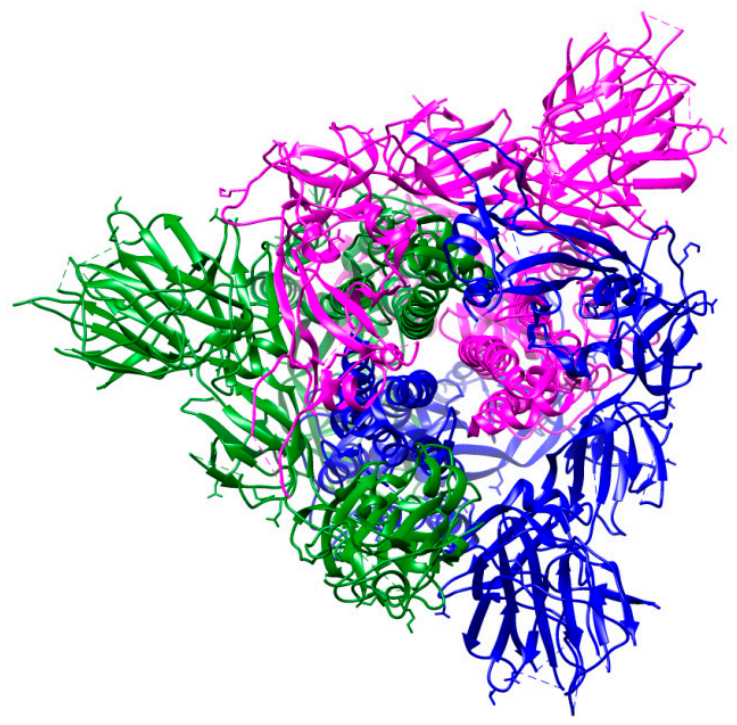

(A)

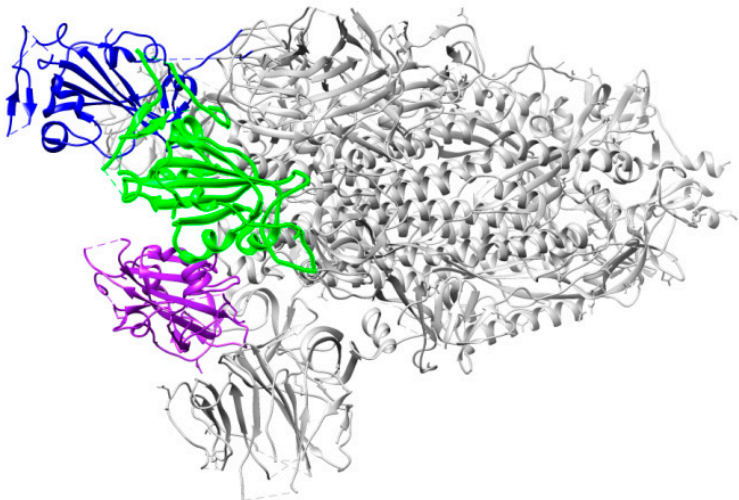

(B)

Figure 1. Cont. 


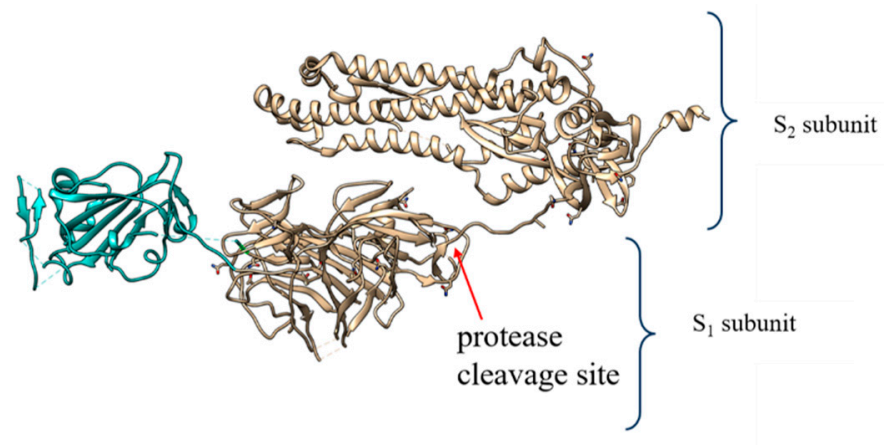

(C)

Figure 1. Overall structure of the $S$ protein protomer of SARS-CoV-2. (A) Each monomer of the $S$ protein protomer is represented by a different color. (B) Receptor-binding sites of the chains A, B, and C of the $\mathrm{S}$ protein are highlighted in blue, purple and green color, respectively. Glycan ligands have been omitted for simplicity. (C) Monomer of the SARS-CoV2 spike protein during the receptor-accessible conformation. The receptor binding domain (RBD) is shown in cyan. Visualized by USCF Chimera [80]. PDB ID: 6VSB.

Glycosylation is one of the most outstanding post-translational modifications in many viral S or envelop proteins, and some researchers argue that the determination of site-specific glycosylation of virus glycoproteins would enable the development of vaccines that take advantage of glycosylation-dependent mechanisms [81]. Mass spectrometric methods have proved to be very useful for quantifying site-specific glycosylation [81,82]. Indeed, mass spectrometry has arisen as a pivotal method for the characterization of numerous virus surface proteins glycosylation in recent years $[83,84]$.

Although genomic methods are very informative for viral mutation or adaptation through immune selective pressure, they cannot inform on that crucial feature of enveloped viruses-viral spike glycosylation. Exploring spike glycosylation and plasticity with advanced mass spectrometric methods using e.g., recombinant preparations compared to wild type viral proteins can be very helpful for a better understanding of the conformational dynamics that shape receptor or antibody binding [84]. The binding of previous coronavirus $\mathrm{S}$ proteins to their respective receptors has been shown by bioinformatics and proteomics approaches to be mediated by its oligomannose $\mathrm{N}$-glycans $[82,85]$. Very recently, Watanabe et al. revealed, by combined mass spectrometric and cryo-EM analysis, how the N-linked glycans occlude distinct regions across the surface of the SARS-CoV-2 spike protein [86]. To resolve the site-specific glycosylation of the SARS-CoV-2 S protein, three kinds of proteases were used to generate glycopeptides that contain a single N-linked glycan sequon. Liquid chromatography-mass spectrometry (LC-MS) analysis determined the glycan composition for all $22 \mathrm{~N}$-linked glycan sites. It was shown that 8 sites contain substantial populations of oligomannose-type glycans, principally N234 and N709 sites, and the remaining 14 sites are dominated by processed, complex-type glycans [86]. This extensive heterogeneity is similar to this of the $S$ proteins of other coronaviruses such as MERS and HKU1, with the broad distribution of oligomannose-type glycans, without one particular dominant peak, as is the case for some viral glycoproteins [87]. Alteration of glycosites can affect viral infectivity, pathogenesis and host responses, e.g., by sterically masking polypeptide epitopes and modulating $S$ protein-receptor interactions. Distinct epitope features between SARS-RBD and SARS-CoV-2-RBD have been shown by studies using murine polyclonal antibodies [88].

It is worth mentioning that all of the glycan sites are conserved on the S2 subunit between SARS-CoV and SARS-CoV-2, whereas the S1 subunit exhibits glycan site additions and deletions. SARS-CoV-2 maintains a total of $22 \mathrm{~N}$-linked glycan sites in comparison with 23 on SARS, with 18 of these sites being in common [87]. 
During viral infection, the spike protein is cleaved into these S1 and S2 subunits by nearby host proteases, such as human airway trypsin-like protease (HAT), cathepsins and transmembrane protease serine 2 (TMPRSS2), and releases the signal peptide to promote virus entry into host cells [7,89]. The proteolytic priming event is usually individual; however, SARS coronavirus entry requires another cleavage (on the S2 domain) by the endosomal protease cathepsin $[90,91]$. That second cleavage activates the protein for the membrane fusion via irreversible conformational changes [92].

Recently, it was revealed that SARS-CoV-2 has a furin cleavage site at the boundary between S1 and S2 that has unique sequence among B-coronaviruses [48]. It had been shown before that the introduction of a furin recognition motif at R667 of SARS-CoV spike glycoprotein allows for efficient cleavage and increased cell-cell fusion activity [93]. The motif of RRAR amino acids in the novel SARS virus, instead of a single arginine, as is present in other similar viruses, allows effective cleavage by furin and other proteases [27,76]. Since furin is highly expressed in lungs, the virus can easily exploit that enzyme to activate its $S$ glycoprotein [76]. Interestingly, Ou et al. discovered that SARS-CoV-2 S protein could trigger syncytia in human receptor cells independently of exogenous protease [77]. The next distinguishing feature of the SARS-CoV-2 spike glycoprotein is the significant variability of its receptor binding domain (RBD). That domain is the most variable part of the coronavirus genome [37,94].

Different coronaviruses use different domains within the S1 subunit to attach to the appropriate receptor [48]. The RBD of the SARS-CoV-2 spike glycoprotein binds directly to the peptidase domain (PD) of the human cell receptor (Figure 2). These small ( $21 \mathrm{kDa}$ each) [51] receptor-binding domains in the whole protomer are depicted in colors in Figure $1 \mathrm{~B}$.

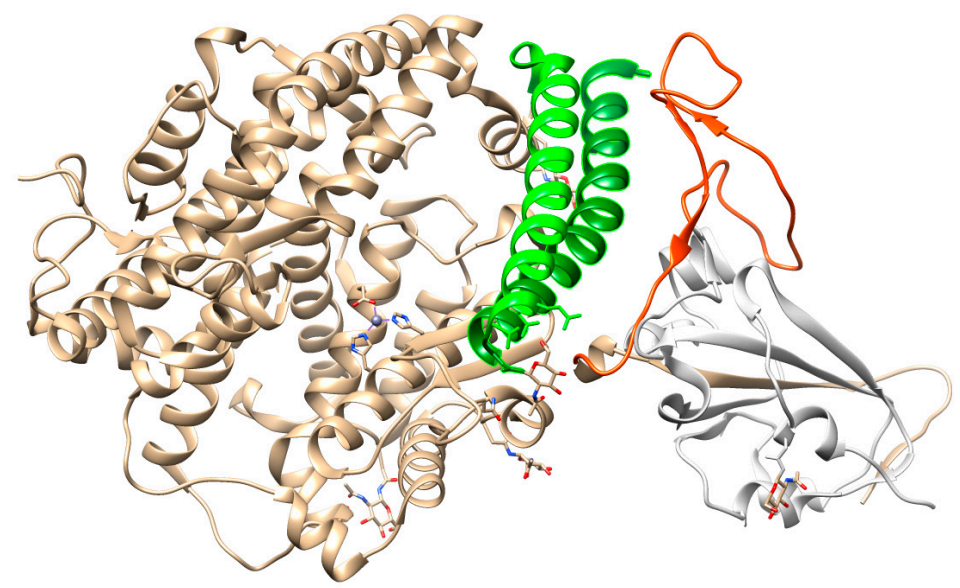

Figure 2. Interactions between SARS-CoV-2 RBD (in orange) and ACE2 (the main interacting $\alpha 1$ helix in dark green, the $\alpha 2$ helix also contributing to the interaction in green), visualized by USCF Chimera. PDB ID: 6M0J.

Many studies have proved that the human angiotensin-converting enzyme (hACE2) is a functional receptor for SARS-CoV-2, similar to other SARS-related coronaviruses [48,63,95]. Zhou et al. showed that only ACE2, and no other coronavirus receptors, such as aminopeptidase N (APN) and dipeptidyl peptidase 4 (DPP4), are used by SARS-CoV-2 as an entry receptor [37]. However, the primary physiological role of ACE2 is catalyzing the hydrolysis of angiotensin II (a vasoconstrictor peptide) into angiotensin heptapeptide (a vasodilator) [96]. ACE2 is an integral membrane metalloproteinase with the N-terminal extracellular domain containing six canonical sequons for N-linked glycosylation and several potential O-linked sites. The occupancy of N-linked glycans, O-linked glycosylation and the heterogeneity of the O-linked glycans on ACE2 have been recently studied using multiple MS-based approaches, including glycomic and glycoproteomic methods [97]. Glycomic analyses revealed that the majority of ACE2 N-glycans are complex, with limited high-mannose and hybrid glycans. That work with the help of molecular dynamics (MD) simulations revealed crucial roles for 
glycosylation, not only in sterically masking polypeptide epitopes, but also in directly modulating spike-ACE2 interactions [97].

To engage the ACE2 receptor, the RBD of S1 undergoes hinge-like conformational motions that transiently hide or expose the determinants of receptor binding, as has been shown by Wrapp et al. [51]. These two states are referred to as "up" and "down" conformations, where "up" corresponds to the receptor-accessible state (Figure 1C). Each PD of homodimeric ACE2 protein accommodates one RBD of spike protein, mainly by the arch-shaped $\alpha 1$ helix $[63,84]$. There is also a limited contribution of the $\alpha 2$ helix, and a loop connecting the $\beta 3$ and $\beta 34$ strands of ACE2 to that binding (Figure 2).

When the RBD is in the "down" conformation, shielding of receptor binding sites on the SARS-CoV-2 S protein by proximal glycosylation sites (N165, N234, N343) can be observed [86].

Interestingly, two glycans on ACE2 (at N090 and N322) have been predicted by MD to form interactions with the $S$ protein. Each of multiple simulations showed N322 glycan interaction with the $S$ trimer, despite its presence outside of the receptor-binding domain. The arms of the ACE2 glycan at N090 were shown to interact with multiple regions of the S trimer surface over the course of the simulations, exposing the relatively high degree of glycan dynamics [97]. Nevertheless, considerable efforts still need to be overtaken in order to fully understand the role of glycans in SARS-CoV-2 infection and pathogenicity.

In the case of SARS-CoV binding to hACE2, structural work identified 14 positions in RBD that are key for that binding: $\mathrm{T}^{402}, \mathrm{R}^{426}, \mathrm{Y}^{436}, \mathrm{Y}^{440}, \mathrm{Y}^{442}, \mathrm{~L}^{472}, \mathrm{~N}^{473}, \mathrm{Y}^{475}, \mathrm{~N}^{479}, \mathrm{Y}^{484}, \mathrm{~T}^{486}, \mathrm{~T}^{487}, \mathrm{G}^{488}$ and $\mathrm{Y}^{491}$ [98]. Analysis of the 144 SARS-CoV-2 genome sequences, done by Walls and co-workers, revealed that 8 out of these 14 positions are strictly conserved, whereas the other 6 ; $R^{426}, Y^{442}, L^{472}, N^{479}, Y^{484}$ and $\mathrm{T}^{487}$ (in SARS-CoV) are (semi)conservatively substituted with $\mathrm{N}^{439}, \mathrm{~L}^{455}, \mathrm{~F}^{486}, \mathrm{Q}^{493}, \mathrm{Q}^{498}$ and $\mathrm{N}^{501}$, respectively (in SARS-CoV-2) [48].

Yan et al. discovered prominent variations and conformational differences in the interfaces of SARS-CoV and SARS-CoV-2 with the ACE 2 receptor [63]. In that work, the most relevant alteration were shown to be the substitution of $\mathrm{Val}^{404}$ in the SARS-CoV-RBD, with $\mathrm{Lys}^{417}$ in the RBD of the virus that is responsible for the current pandemic.

It was suggested that the substitution of other residues ( $\mathrm{Tyr}^{442}$ to $\mathrm{Leu}^{455}, \mathrm{Leu}^{443}$ to $\mathrm{Phe}^{456}$, $\mathrm{Phe}^{460}$ to $\mathrm{Tyr}^{473}$, and $\mathrm{Asn}^{479}$ to $\mathrm{Gln}^{493}$ ) may also influence the affinity for the human cell receptor [63] (highlighted in yellow in Figure 3). Superimposition of the SARS-CoV-2 C-terminal domain (encompassing RBD) structure onto the SARS-RBD structure revealed that the majority of the secondary structure elements are well superimposed in that domain [87]. However, cryo-electron microscopy studies were done in the presence of the neutral amino acid transporter $\mathrm{B}^{0} \mathrm{AT} 1$, which could be the reason for the some divergence of the results compared to the work of Walls et al. [48].

Nonetheless, as shown by Wang et al. among 24 residues in hACE2 that make van der Waals contacts with both RBDs, 15 amino acids exhibit more contacts with the SARS-CoV-2 C terminal domain [87]. Consistently, the SARS-CoV-2 RBD also has more residues than SARS-CoV RBD that directly interact with ACE2, forming vdw contacts and H-bonds. In that work, F486 in SARS-CoV-2, instead of L472 in SARS-CoV, was shown to form strong aromatic-aromatic interactions with Y83 residue of ACE2, and E484 in SARS-CoV-2 instead of P470 in SARS-CoV, formed ionic interactions with receptor's K31 residue [87].

It has been shown, using biolayer interferometry, that the SARS-CoV-2 $\mathrm{S}^{\mathrm{B}}$ (binding) domain engages human receptor with comparable affinity to SARS-CoV S ${ }^{\mathrm{B}}$ from viral isolates associated with the 2002-2003 epidemic [48]. On the other hand, Wrapp et al. showed that ACE2 binds to the SARS-CoV-2 ectodomain 10- to 20-fold more tightly than to SARS-CoV [51]. Similarly, Wang et al. found that SARS-CoV-2 RBD displays approximately 4-fold stronger affinity towards hACE2 than SARS-RBD. The equilibrium dissociation constant $\left(\mathrm{K}_{\mathrm{D}}\right)$ of SARS-CoV-2 RBD binding to ACE2 was calculated to be $133.3 \pm 5.6 \mathrm{nM}$ [87]. Surprisingly, computational analyses predicted that the SARS-CoV-2 RBD sequence is not optimal for receptor binding [79]. 


\begin{abstract}
2AJF 1 CPFGEVFNATKFPSVYAWERKKISNCVADYSVLYNSTFFSTFKCYGVSATKLNDLCFSNV
6LZG 1 CPFGEVFNATRFASVYAWNRKRISNCVADYSVLYNSASFSTFKCYGVSPTKLNDLCFTNV

6M0J 1 CPFGEVFNATRFASVYAWNRKRISNCVADYSVLYNSASFSTFKCYGVSPTKLNDLCETNV

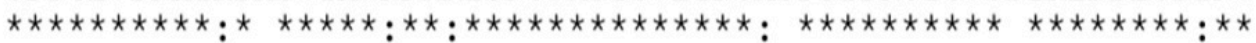

2AJF

6LZG

61 YADSFVVKGDDVRQIAPGQTGVIADYNYKLPDDFMGCVLAWNTRNIDATSTGNYNYKYRY

$6 \mathrm{MOJ}$

61 YADSFVIRGDEVRQIAPGQTGKIADYNYKLPDDFTGCVIAWNSNNLDSKVGGNYNYLYRL

61 YADSFVIRGDEVRQIAPGQTGKIADYNYKLPDDFTGCVIAWNSNNLDSKVGGNYNYLYRL

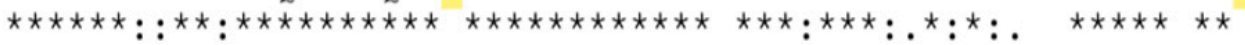

2AJF 121 LRHGKLRPFERDISNVPFSPDGKPCTP-PALNCYWPLNDYGFYTTTGIGYQPYRVVVLSF 6LZG 121 FRKSNLKPFERDISTEIYQAGSTPCNGVEGFNCYFPLQSYGFQPTNGVGYQPYRVVVLSF 6M0J 121 FRKSNLKPFERDISTEIYQAGSTPCNGVEGFNCYFPLQSYGEQPTNGVGYQPYRVVVLSF

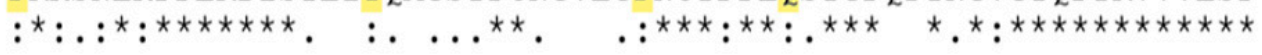

Figure 3. Comparison of the SARS-CoV-RBD/hACE2 and SARS-CoV-2 RBD/hACE2 binding sites. The most prominent substitutions are highlighted in yellow. 2AJF stands for PDB ID of the receptor binding domain of SARS-CoV; below the RBD sequences of the SARS-CoV-2 S1 protein (PDB IDs: 6LZG and 6M0J).

There are other analytical and biophysical tools which can provide detailed information on the binding affinity of the biomolecules, such as Förster resonance energy transfer (FRET) and biosensors (also FRET-based biosensors) [99-101], and isothermal titration calorimetry (ITC) [102-104], however, this is not in the scope of this review. The choice of the experimental strategy is usually dictated by the proteins under investigation. Optical biosensors for studies on protein interactions, their advantages and limitations have been thoroughly reviewed by Zhao et al. [105].

The usage of other orthogonal methods supporting MS, X-ray crystallography and cryo-electron microscopy, can give the more detailed insight into the S protein-ACE2 interaction, and find protein targets for the discovery and development of anti-coronavirus therapy $[63,99,106]$.

It is worth mentioning that, five years after the first SARS outbreak, a range of candidate vaccines have been developed. However, as of July 2020, there are no approved vaccines or drugs against any human-infecting CoV infections [48,53,104].

Before, despite intensive work on SARS-CoV protease inhibitors, none of the studied compounds have gone through a complete preclinical development program, mainly because of sharp funding cuts in most countries in 2005-2006 [106].

There are suggestions that some medicines and vaccines against SARS-CoV could probably have been used to treat infections with the SARS-CoV-2 virus. THis drug repurposing strategy could significantly shorten the time and reduce the cost in comparison to de novo drug discovery and randomized clinical trials [107].

However, Wang et al. showed that, despite the structural similarity of RBD of SARS-CoV and SARS-CoV-2, they exhibit different epitope features and differing immunogenicity [86]. On the other hand, Tai and co-workers revealed that SARS-CoV RBD-induced antibodies could cross-react with SARS-CoV-2 RBD and cross-neutralize SARS-CoV-2 pseudovirus infection, suggesting that SARS-CoV RBD-specific antibodies may be used for treatment of SARS-CoV-2 infection [108].

More studies are needed to explore the pathogenicity mechanism of SARS-CoV-2, particularly to uncover the mystery of the molecular mechanism of viral entry into host cells and replication. Such studies will provide the basis for future research on developing targeted antiviral drugs and vaccines [109].

Since the outbreak at the end of 2019, scientists have been working extensively on therapies and vaccines against the novel coronavirus. Treatments and vaccines not only have to be proven effective against the virus, but must also be safe for people. 
Deeper investigation into the spike protein-human cell receptor/s interactions may provide early scientific guidance for viral prevention and control.

\section{Conclusions and Future Perspectives}

As of 31 August, 25,118,689 cases of COVID-19 have been confirmed in 213 countries and territories around the world. As of that day, approximately 844,000 people have not been able to overcome this disease [110].

The situation with COVID-19 brings the questions: when will it end and what will be next? There is a hypothesis that SARS-CoV-2 will enter the group of the "seasonal infections" in the future [35]. At this moment, despite the many scientific groups working on it, we have only a partial knowledge about this novel virus and its interactions with human cells. Moreover, another adaptive process could result in a virus with even higher infectiousness and transmissibility in humans.

Furthermore, there are many other species of coronaviruses in animals that can become global health threats. For these reasons, deep studies joining together researchers from the frontiers of biology and chemistry, epidemiologists and doctors are clearly of utmost importance.

This review provides insights into the COVID-19 current situation, with a special emphasis on the current state of the art in terms of the SARS-CoV-2 S protein and human cell receptor protein interactions. From the lessons learned during the SARS-CoV and SARS-CoV-2 epidemics, we can improve on the handling of global pandemics or epidemics. The clear, reliable and timely dissemination of information is also crucial in dealing with the epidemic.

Mass spectrometry methods are utilized in studies on virus $S$ protein and receptor protein glycosylation and interaction, revealing targets for neutralizing antibodies elicited through vaccination. Moreover, multi-omic profiling of the host response could be helpful in tracking disease, and prevent future pandemics of similar viruses.

Funding: This research received no external funding.

Conflicts of Interest: The author declares no conflict of interest.

\section{References}

1. Pal, M.; Berhanu, G.; Desalegn, C.; Kandi, V. Severe acute respiratory syndrome Coronavirus-2 (SARS-CoV-2): An update. Cureus 2020, 12, e7423. [CrossRef] [PubMed]

2. Zaki, A.M.; van Boheemen, S.; Bestebroer, T.M.; Osterhaus, A.D.M.E.; Fouchier, R.A.M. Isolation of a novel coronavirus from a man with pneumonia in Saudi Arabia. N. Engl. J. Med. 2012, 367, 1814-1820. [CrossRef] [PubMed]

3. Rabaan, A.A. Middle East respiratory syndrome coronavirus: Five years later. Expert Rev. Respir. Med. 2017, 11, 901-912. [CrossRef]

4. Su, S.; Wong, G.; Shi, W.; Liu, J.; Lai, A.C.K.; Zhou, J.; Liu, W.; Bi, Y.; Gao, G.F. Epidemiology, genetic recombination, and pathogenesis of coronaviruses. Trends Microbiol. 2016, 24, 490-502. [CrossRef] [PubMed]

5. Alraddadi, B.M.; Watson, J.T.; Almarashi, A.; Abedi, G.R.; Turkistani, A.; Sadran, M.; Housa, A.; Almazroa, M.A.; Alraihan, N.; Banjar, A.; et al. Risk factors for primary Middle East respiratory syndrome coronavirus illness in humans, Saudi Arabia, 2014. Emerg. Infect. Dis. 2016, 22, 49-55. [CrossRef] [PubMed]

6. Sikkema, R.S.; Farag, E.A.B.A.; Himatt, S.; Ibrahim, A.K.; Al-Romaihi, H.; Al-Marri, S.A.; Al-Thani, M.; El-Sayed, A.M.; Al-Hajri, M.; Haagmans, B.L.; et al. Risk Factors for Primary Middle East Respiratory Syndrome Coronavirus Infection in Camel Workers in Qatar During 2013-2014: A Case-Control Study. J. Infect. Dis. 2017, 215, 1702-1705. [CrossRef] [PubMed]

7. Yang, Y.S.; Peng, F.J.; Wang, R.S.; Guan, K.; Jiang, T.J.; Xu, G.G.; Sun, J.Y.; Chang, R.O.E. The deadly coronaviruses: The 2003 SARS pandemic and the 2020 novel coronavirus epidemic in China. J. Autoimmun. 2020, 109, 102434. [CrossRef]

8. Fung, T.S.; Liu, D.X. Coronavirus infection, ER stress, apoptosis and innate immunity. Annu. Rev. Microbiol. 2019, 73, 529-557. [CrossRef] 
9. Almeida, J.D.; Berry, D.M.; Cunningham, C.H.; Hamre, D.; Hofstad, M.S.; Mallucci, L.; McIntosh, K.; Tyrrell, D.A.J. Coronaviruses. Nature 1968, 220, 650.

10. Payne, S. Viruses: From Understanding to Investigation; Academic Press: Cambridge, MA, USA, 2017; pp. 149-158.

11. Woo, P.C.Y.; Wang, M.; Lau, S.K.P.; Xu, H.; Poon, R.W.S.; Guo, R.; Wong, B.H.L.; Gao, K.; Tsoi, H.-W.; Huang, Y.; et al. Comparative analysis of twelve genomes of three novel group $2 \mathrm{c}$ and group $2 \mathrm{~d}$ coronaviruses reveals unique group and subgroup features. J. Virol. 2007, 81, 1574-1585. [CrossRef]

12. Zhang, W.; Zheng, X.-S.; Agwanda, B.; Ommeh, S.; Zhao, K.; Lichoti, J.; Wang, N.; Chen, J.; Li, B.; Yang, X.-L.; et al. Serological evidence of MERS-CoV and HKU8-related CoV co-infection in Kenyan camels. Emerg. Microbes Infect. 2019, 8, 1528-1534. [CrossRef] [PubMed]

13. Reusken, C.B.E.M.; Haagmans, B.L.; Mueller, M.A.; Gutierrez, C.; Godeke, G.-J.; Meyer, B.; Muth, D.; Raj, V.S.; Vries, L.S.; Corman, V.M.; et al. Middle East respiratory syndrome coronavirus neutralising serum antibodies in dromedary camels: A comparative serological study. Lancet Infect. Dis. 2013, 13, 859-866. [CrossRef]

14. Ge, X.-Y.; Yang, W.-H.; Zhou, J.-H.; Li, B.; Zhang, W.; Shi, Z.-L.; Zhang, Y.-Z. Detection of alpha- and betacoronaviruses in rodents from Yunnan, China. Virol. J. 2017, 14, 98. [CrossRef] [PubMed]

15. Lau, S.K.P.; Woo, P.C.Y.; Yip, C.C.Y.; Fan, R.Y.Y.; Huang, Y.; Wang, M.; Guo, R.; Lam, C.S.F.; Tsang, A.K.L.; Lai, K.K.Y.; et al. Isolation and characterization of a novel Betacoronavirus subgroup A coronavirus, rabbit coronavirus HKU14, from domestic rabbits. J. Virol. 2012, 86, 5481-5496. [CrossRef]

16. Rabi, F.A.; al Zoubi, M.S.; Kasasbeh, G.A.; Salameh, D.M.; Al-Nasser, A.D. SARS-CoV-2 and Coronavirus Disease 2019: What We Know So Far. Pathogens 2020, 9, 231. [CrossRef] [PubMed]

17. Song, H.D.; Tu, C.C.; Zhang, G.W.; Wang, S.Y.; Zheng, K.; Lei, L.C.; Chen, Q.X.; Gao, Y.W.; Zhou, H.Q.; Xiang, H.; et al. Cross-host evolution of severe acute respiratory syndrome coronavirus in palm civet and human. Proc. Natl. Acad. Sci. USA 2005, 102, 2430-2435. [CrossRef]

18. Yan, Y.; Chang, L.; Wang, L. Laboratory testing of SARS-CoV, MERS-CoV, and SARS-CoV-2 (2019-nCoV): Current status, challenges, and countermeasures. Rev. Med. Virol. 2020, e2106. [CrossRef]

19. Song, Z.; Xu, Y.; Bao, L.; Zhang, L.; Yu, P.; Qu, Y.; Zhu, H.; Zhao, W.; Han, Y.; Qin, C. From SARS to MERS, Thrusting Coronaviruses into the Spotlight. Viruses-Basel 2019, 11, 59. [CrossRef]

20. Zhu, N.; Zhang, D.; Wang, W.; Li, X.; Yang, B.; Song, J.; Zhao, X.; Huang, B.; Shi, W.; Lu, R.; et al. A Novel Coronavirus from Patients with Pneumonia in China, 2019. N. Engl. J. Med. 2020, 382, 727-733. [CrossRef]

21. Chen, N.; Zhou, M.; Dong, X.; Qu, J.; Gong, F.; Han, Y.; Qiu, Y.; Wang, J.; Liu, Y.; Wei, Y.; et al. Epidemiological and clinical characteristics of 99 cases of 2019 novel coronavirus pneumonia in Wuhan, China: A descriptive study. Lancet 2020, 395, 507-513. [CrossRef]

22. Chan, J.F.-W.; Yuan, S.; Kok, K.-H.; To, K.K.-W.; Chu, H.; Yang, J.; Xing, F.; Liu, J.; Yip, C.C.-Y.; Poon, R.W.-S.; et al. A familial cluster of pneumonia associated with the 2019 novel coronavirus indicating person-to-person transmission: A study of a family cluster. Lancet 2020, 395, 514-523. [CrossRef]

23. Lu, R.; Zhao, X.; Li, J.; Niu, P.; Yang, B.; Wu, H.; Wang, W.; Song, H.; Huang, B.; Zhu, N.; et al. Genomic characterisation and epidemiology of 2019 novel coronavirus: Implications for virus origins and receptor binding. Lancet 2020, 395, 565-574. [CrossRef]

24. Bordi, L.; Nicastri, E.; Scorzolini, L.; di Caro, A.; Capobianchi, M.R.; Castilletti, C.; Lalle, E.; Grp, I.C.-S. Differential diagnosis of illness in patients under investigation for the novel coronavirus (SARS-CoV-2), Italy, February 2020. Eurosurveillance 2020, 25, 2-5. [CrossRef] [PubMed]

25. Gabutti, G.; d'Anchera, E.; Sandri, F.; Savio, M.; Stefanati, A. Coronavirus: Update Related to the Current Outbreak of COVID-19. Infect. Dis. Ther. 2020, 9, 1-13. [CrossRef] [PubMed]

26. Abduljalil, J.M.; Abduljalil, B.M. Epidemiology, genome, and clinical features of the pandemic SARS-CoV-2: A recent view. New Microbes New Infect. 2020, 35, 100672. [CrossRef]

27. Andersen, K.G.; Rambaut, A.; Lipkin, W.I.; Holmes, E.C.; Garry, R.F. The proximal origin of SARS-CoV-2. Nat. Med. 2020, 26, 450-452. [CrossRef] [PubMed]

28. Day, M. Covid-19: Identifying and isolating asymptomatic people helped eliminate virus in Italian village. BMJ Br. Med. J. 2020, 368, m1165. [CrossRef]

29. Qiu, H.; Wu, J.; Hong, L.; Luo, Y.; Song, Q.; Chen, D. Clinical and epidemiological features of 36 children with coronavirus disease 2019 (COVID-19) in Zhejiang, China: An observational cohort study. Lancet. Infect. Dis. 2020, 20, 689-696. [CrossRef] 
30. Tang, A.; Tong, Z.-D.; Wang, H.-L.; Dai, Y.-X.; Li, K.-F.; Liu, J.-N.; Wu, W.-J.; Yuan, C.; Yu, M.-L.; Li, P.; et al. Detection of Novel Coronavirus by RT-PCR in Stool Specimen from Asymptomatic Child, China. Emerg. Infect. Dis. 2020, 26, 1337-1339. [CrossRef]

31. Wang, D.W.; Hu, B.; Hu, C.; Zhu, F.F.; Liu, X.; Zhang, J.; Wang, B.B.; Xiang, H.; Cheng, Z.S.; Xiong, Y.; et al. Clinical Characteristics of 138 Hospitalized Patients With 2019 Novel Coronavirus-Infected Pneumonia in Wuhan, China. JAMA J. Am. Med Assoc. 2020, 323, 1061-1069. [CrossRef]

32. Li, Q.; Guan, X.; Wu, P.; Wang, X.; Zhou, L.; Tong, Y.; Ren, R.; Leung, K.S.M.; Lau, E.H.Y.; Wong, J.Y.; et al. Early Transmission Dynamics in Wuhan, China, of Novel Coronavirus-Infected Pneumonia. N. Engl. J. Med. 2020, 382, 1199-1207. [CrossRef] [PubMed]

33. Koo, J.R.; Cook, A.R.; Park, M.; Sun, Y.; Sun, H.; Lim, J.T.; Tam, C.; Dickens, B.L. Interventions to mitigate early spread of SARS-CoV-2 in Singapore: A modelling study. Lancet Infect. Dis. 2020, 20, 678-688. [CrossRef]

34. Liu, Y.; Gayle, A.A.; Wilder-Smith, A.; Rocklov, J. The reproductive number of COVID-19 is higher compared to SARS coronavirus. J. Travel Med. 2020. [CrossRef]

35. Ceccarelli, M.; Berretta, M.; Rullo, E.V.; Nunnari, G.; Cacopardo, B. Differences and similarities between Severe Acute Respiratory Syndrome (SARS)-CoronaVirus (CoV) and SARS-CoV-2. Would a rose by another name smell as sweet? Eur. Rev. Med Pharmacol. Sci. 2020, 24, 2781-2783. [PubMed]

36. Kannan, S.; Ali, P.S.S.; Sheeza, A.; Hemalatha, K. COVID-19 (Novel Coronavirus 2019)-recent trends. Eur. Rev. Med Pharmacol. Sci. 2020, 24, 2006-2011. [PubMed]

37. Zhou, P.; Yang, X.L.; Wang, X.G.; Hu, B.; Zhang, L.; Zhang, W.; Si, H.R.; Zhu, Y.; Li, B.; Huang, C.L.; et al. A pneumonia outbreak associated with a new coronavirus of probable bat origin. Nature 2020, 579, 270. [CrossRef]

38. Lau, S.K.P.; Luk, H.K.H.; Wong, A.C.P.; Li, K.S.M.; Zhu, L.; He, Z.; Fung, J.; Chan, T.T.Y.; Fung, K.S.C.; Woo, P.C.Y. Possible Bat Origin of Severe Acute Respiratory Syndrome Coronavirus 2. Emerg. Infect. Dis. 2020, 26, 1542-1547. [CrossRef] [PubMed]

39. Chu, D.K.W.; Pan, Y.; Cheng, S.M.S.; Hui, K.P.Y.; Krishnan, P.; Liu, Y.Z.; Ng, D.Y.M.; Wan, C.K.C.; Yang, P.; Wang, Q.Y.; et al. Molecular Diagnosis of a Novel Coronavirus (2019-nCoV) Causing an Outbreak of Pneumonia. Clin. Chem. 2020, 66, 549-555. [CrossRef]

40. Hu, B.; Zeng, L.-P.; Yang, X.-L.; Ge, X.-Y.; Zhang, W.; Li, B.; Xie, J.-Z.; Shen, X.-R.; Zhang, Y.-Z.; Wang, N.; et al. Discovery of a rich gene pool of bat SARS-related coronaviruses provides new insights into the origin of SARS coronavirus. PLoS Pathog. 2017, 13, e1006698. [CrossRef] [PubMed]

41. Khailany, R.A.; Safdar, M.; Ozaslan, M. Genomic characterization of a novel SARS-CoV-2. Gene. Rep. 2020, 19, 100682. [CrossRef]

42. Chang, M.S.; Lu, Y.T.; Ho, S.T.; Wu, C.C.; Wei, T.Y.; Chen, C.J.; Hsu, Y.T.; Chu, P.C.; Chen, C.H.; Chu, J.M.; et al. Antibody detection of SARS-CoV spike and nucleocapsid protein. Biochem. Biophys. Res. Commun. 2004, 314, 931-936. [CrossRef] [PubMed]

43. Prajapat, M.; Sarma, P.; Shekhar, N.; Avti, P.; Sinha, S.; Kaur, H.; Kumar, S.; Bhattacharyya, A.; Kumar, H.; Bansal, S.; et al. Drug targets for corona virus: A systematic review. Indian J. Pharmacol. 2020, 52, 56-65. [PubMed]

44. Perlman, S.; Netland, J. Coronaviruses post-SARS: Update on replication and pathogenesis. Nat. Rev. Microbiol. 2009, 7, 439-450. [CrossRef] [PubMed]

45. Weiss, S.R.; Leibowitz, J.L. Coronavirus pathogenesis. Adv. Virus Res. 2011, 81, 85-164.

46. Tan, Y.J.; Teng, E.; Shen, S.; Tan, T.H.; Goh, P.Y.; Fielding, B.C.; Ooi, E.E.; Tan, H.C.; Lim, S.G.; Hong, W. A novel severe acute respiratory syndrome coronavirus protein, $\mathrm{U} 274$, is transported to the cell surface and undergoes endocytosis. J. Virol. 2004, 78, 6723-6734. [CrossRef]

47. Narayanan, K.; Huang, C.; Makino, S. SARS coronavirus accessory proteins. Virus Res. 2008, 133, $113-121$. [CrossRef]

48. Walls, A.C.; Park, Y.-J.; Tortorici, M.A.; Wall, A.; McGuire, A.T.; Veesler, D. Structure, Function, and Antigenicity of the SARS-CoV-2 Spike Glycoprotein. Cell 2020, 181, 281-292. [CrossRef]

49. Meyer, B.; Drosten, C.; Mueller, M.A. Serological assays for emerging coronaviruses: Challenges and pitfalls. Virus Res. 2014, 194, 175-183. [CrossRef]

50. Versteeg, G.A.; van de Nes, P.S.; Bredenbeek, P.J.; Spaan, W.J.M. The coronavirus spike protein induces endoplasmic reticulum stress and upregulation of intracellular chemokine mRNA concentrations. J. Virol. 2007, 81, 10981-10990. [CrossRef] 
51. Wrapp, D.; Wang, N.S.; Corbett, K.S.; Goldsmith, J.A.; Hsieh, C.L.; Abiona, O.; Graham, B.S.; McLellan, J.S. Cryo-EM structure of the 2019-nCoV spike in the prefusion conformation. Science 2020, 367, 1260. [CrossRef]

52. Tilocca, B.; Soggiu, A.; Sanguinetti, M.; Musella, V.; Britti, D.; Bonizzi, L.; Urbani, A.; Roncada, P. Comparative computational analysis of SARS-CoV-2 nucleocapsid protein epitopes in taxonomically related coronaviruses. Microbes Infect. 2020, 22, 188-194. [CrossRef] [PubMed]

53. Li, G.; Fan, Y.; Lai, Y.; Han, T.; Li, Z.; Zhou, P.; Pan, P.; Wang, W.; Hu, D.; Liu, X.; et al. Coronavirus infections and immune responses. J. Med. Virol. 2020, 92, 424-432. [CrossRef] [PubMed]

54. Delamater, P.L.; Street, E.J.; Leslie, T.F.; Yang, Y.T.; Jacobsen, K.H. Complexity of the Basic Reproduction Number $\left(\mathrm{R}_{0}\right)$. Emerg. Infect. Dis. 2019, 25, 1-4. [CrossRef] [PubMed]

55. Zhang, J.; Lin, G.; Zeng, J.; Lin, J.; Tian, J.; Li, G. Challenges of SARS-CoV-2 and lessons learnt from SARS in Guangdong Province, China. Journal of Clinical Virology: The Official Publication of the Pan American Society for Clinical Virology. J. Clin. Virol. Off. Publ. Pan Am. Soc. Clin. Virol. 2020, 126, 104341. [CrossRef]

56. Ksiazek, T.G.; Erdman, D.; Goldsmith, C.S.; Zaki, S.R.; Peret, T.; Emery, S.; Tong, S.X.; Urbani, C.; Comer, J.A.; Lim, W.; et al. A Novel Coronavirus Associated with Severe Acute Respiratory Syndrome. N. Engl. J. Med. 2003, 348, 1953-1966. [CrossRef]

57. Feng, Y.; Gao, G.F. Towards our understanding of SARS-CoV, an emerging and devastating but quickly conquered virus. Comp. Immunol. Microbiol. Infect. Dis. 2007, 30, 309-327. [CrossRef]

58. Hui, D.S.; Azhar, E.I.; Madani, T.A.; Ntoumi, F.; Kock, R.; Dar, O.; Ippolito, G.; McHugh, T.D.; Memish, Z.A.; Drosten, C.; et al. The continuing 2019-nCoV epidemic threat of novel coronaviruses to global health-The latest 2019 novel coronavirus outbreak in Wuhan, China. Int. J. Infect. Dis. 2020, 91, 264-266. [CrossRef]

59. Wassenaar, T.M.; Zou, Y. 2019_nCoV/SARS-CoV-2: Rapid classification of betacoronaviruses and identification of Traditional Chinese Medicine as potential origin of zoonotic coronaviruses. Lett. Appl. Microbiol. 2020, 70, 342-348. [CrossRef]

60. Wang, M.; Yan, M.Y.; Xu, H.F.; Liang, W.; Kan, B.; Zheng, B.J.; Chen, H.L.; Zheng, H.; Xu, Y.M.; Zhang, E.M.; et al. SARSCoV infection in a restaurant from palm civet. Emerg. Infect. Dis. 2005, 11, 1860-1865. [CrossRef]

61. Kan, B.; Wang, M.; Jing, H.Q.; Xu, H.F.; Jiang, X.G.; Yan, M.Y.; Liang, W.L.; Zheng, H.; Wan, K.L.; Liu, Q.Y.; et al. Molecular evolution analysis and geographic investigation of severe acute respiratory syndrome coronavirus-like virus in palm civets at an animal market and on farms. J. Virol. 2005, 79, 11892-11900. [CrossRef]

62. Tian, X.; Li, C.; Huang, A.; Xia, S.; Lu, S.; Shi, Z.; Lu, L.; Jiang, S.; Yang, Z.; Wu, Y.; et al. Potent binding of 2019 novel coronavirus spike protein by a SARS coronavirus-specific human monoclonal antibody. Emerg. Microbes Infect. 2020, 9, 382-385. [CrossRef] [PubMed]

63. Yan, R.H.; Zhang, Y.Y.; Li, Y.N.; Xia, L.; Guo, Y.Y.; Zhou, Q. Structural basis for the recognition of SARS-CoV-2 by full-length human ACE2. Science 2020, 367, 1444-1448. [CrossRef] [PubMed]

64. Shang, J.; Ye, G.; Shi, K.; Wan, Y.; Luo, C.; Aihara, H.; Geng, Q.; Auerbach, A.; Li, F. Structural basis of receptor recognition by SARS-CoV-2. Nature 2020. [CrossRef] [PubMed]

65. Riou, J.; Althaus, C.L. Pattern of early human-to-human transmission of Wuhan 2019 novel coronavirus (2019-nCoV), December 2019 to January 2020. Eurosurveillance 2020, 25, 7-11. [CrossRef]

66. Chen, J. Pathogenicity and transmissibility of 2019-nCoVdA quick overviewand comparison with other emerging viruses. Microbes Infect. 2020, 22, 69-71. [CrossRef]

67. Huang, C.; Wang, Y.; Li., X.; Ren, L.; Zhao, J.; Hu, Y.; Zhang, L.; Fan, G.; Xu, J.; Gu, X.; et al. Clinical features of patients infected with 2019 novel coronavirus in Wuhan, China. Lancet 2020, 395, 497-506. [CrossRef]

68. Shereen, M.A.; Khan, S.; Kazmi, A.; Bashir, N.; Siddique, R. COVID-19 infection: Origin, transmission, and characteristics of human coronaviruses. J. Adv. Res. 2020, 24, 91-98. [CrossRef]

69. Wang, C.; Horby, P.W.; Hayden, F.G.; Gao, G.F. A novel coronavirus outbreak of global health concern. Lancet 2020, 395, 470-473. [CrossRef]

70. Gordon, D.E.; Jang, G.M.; Bouhaddou, M.; Xu, J.; Obernier, K.; White, K.M.; O’Meara, M.J.; Rezelj, V.V.; Guo, J.Z.; Swaney, D.L.; et al. A SARS-CoV-2 protein interaction map reveals targets for drug repurposing. Nature 2020, 583, 459-468. [CrossRef]

71. Poran, A.; Harjanto, D.; Malloy, M.; Arieta, C.M.; Rothenberg, D.A.; Lenkala, D.; van Buuren, M.M.; Addona, T.A.; Rooney, M.S.; Srinivasan, L.; et al. Sequence-based prediction of SARS-CoV-2 vaccine targets using a mass spectrometry-based bioinformatics predictor identifies immunogenic $\mathrm{T}$ cell epitopes. Genome Med. 2020, 12, 70. [CrossRef] 
72. Li, C.K.; Wu, H.; Yan, H.; Ma, S.; Wang, L.; Zhang, M.; Tang, X.; Temperton, N.J.; Weiss, R.A.; Brenchley, J.M.; et al. T cell responses to whole SARS coronavirus in humans. J. Immunol. 2008, 181, 5490-5500. [CrossRef]

73. Weiskopf, D.; Schmitz, K.S.; Raadsen, M.P.; Grifoni, A.; Okba, N.M.A.; Endeman, H.; van den Akker, J.P.; Molenkamp, R.; Koopmans, M.P.; van Gorp, E.C.; et al. Phenotype and kinetics of SARS-CoV-2-specific T cells in COVID-19 patients with acute respiratory distress syndrome. Sci. Immunol. 2020, 5, eabd2071. [CrossRef] [PubMed]

74. Belouzard, S.; Millet, J.K.; Licitra, B.N.; Whittaker, G.R. Mechanisms of coronavirus cell entry mediated by the viral spike protein. Viruses 2012, 4, 1011-1033. [CrossRef] [PubMed]

75. Tay, M.Z.; Poh, C.M.; Rénia, L.; MacAry, P.A.; Ng, L.F. The trinity of COVID-19: Immunity, inflammation and intervention. Nat. Rev. Immunol. 2020, 20, 363-374. [CrossRef] [PubMed]

76. Coutard, B.; Valle, C.; de Lamballerie, X.; Canard, B.; Seidah, N.G.; Decroly, E. The spike glycoprotein of the new coronavirus 2019-nCoV contains a furin-like cleavage site absent in CoV of the same clade. Antivir. Res. 2020, 176, 104742. [CrossRef] [PubMed]

77. Ou, X.Y.; Liu, Y.; Lei, X.B.; Li, P.; Mi, D.; Ren, L.L.; Guo, L.; Guo, R.X.; Chen, T.; Hu, J.X.; et al. Characterization of spike glycoprotein of SARS-CoV-2 on virus entry and its immune cross-reactivity with SARS-CoV. Nat. Commun. 2020, 11, 1620. [CrossRef] [PubMed]

78. Heald-Sargent, T.; Gallagher, T. Ready, set, fuse! The coronavirus spike protein and acquisition of fusion competence. Viruses-Basel 2012, 4, 557-580. [CrossRef]

79. Wan, Y.S.; Shang, J.; Graham, R.; Baric, R.S.; Li, F. Receptor Recognition by the Novel Coronavirus from Wuhan: An Analysis Based on Decade-Long Structural Studies of SARS Coronavirus. J. Virol. 2020, 94, e00127-20. [CrossRef]

80. Pettersen, E.F.; Goddard, T.D.; Huang, C.C.; Couch, G.S.; Greenblatt, D.M.; Meng, E.C.; Ferrin, T.E. UCSF Chimera-A Visualization System for Exploratory Research and Analysis. J. Comput. Chem. 2004, 25, 1605-1612. [CrossRef]

81. Chang, D.; Zaia, J. Why Glycosylation Matters in Building a Better Flu Vaccine. Mol. Cell. Proteom. 2019, 18, 2348-2358. [CrossRef]

82. Parsons, L.M.; Bouwman, K.M.; Azurmendi, H.; de Vries, R.P.; Cipollo, J.F.; Verheije, M.H. Glycosylation of the viral attachment protein of avian coronavirus is essential for host cell and receptor binding. J. Biol. Chem. 2019, 294, 7797-7809. [CrossRef] [PubMed]

83. Hargett, A.; Renfrow, M. Glycosylation of viral surface proteins probed by mass spectrometry. Curr. Opin. Virol. 2019, 36, 56-66. [CrossRef] [PubMed]

84. Struwe, W.; Emmott, E.; Bailey, M.; Sharon, M.; Sinz, A.; Corrales, F.J.; Thalassinos, K.; Braybrook, J.; Mills, C.; Barran, P. The COVID-19 MS Coalition-accelerating diagnostics, prognostics, and treatment. Lancet 2020, 395, 1761-1762. [CrossRef]

85. Zheng, J.; Yamada, Y.; Fung, T.S.; Huang, M.; Chia, R.; Liu, D.X. Identification of N-linked glycosylation sites in the spike protein and their functional impact on the replication and infectivity of coronavirus infectious bronchitis virus in cell culture. Virology 2018, 513, 65-74. [CrossRef]

86. Watanabe, Y.; Allen, J.D.; Wrapp, D.; McLellan, J.S.; Crispin, M. Site-specific glycan analysis of the SARS-CoV-2 spike. Science 2020, 369, 330-333. [CrossRef]

87. Watanabe, Y.; Berndsen, Z.T.; Raghwani, J.; Seabright, G.E.; Allen, J.D.; Pybus, O.G.; McLellan, J.S.; Wilson, I.A.; Bowden, T.A.; Ward, A.B.; et al. Vulnerabilities in coronavirus glycan shields despite extensive glycosylation. Nat. Commun. 2020, 11, 2688. [CrossRef]

88. Wang, Q.; Zhang, Y.; Wu, L.; Niu, S.; Song, C.; Zhang, Z.; Lu, G.; Qiao, C.; Hu, Y.; Yuen, K.-Y.; et al. Structural and Functional Basis of SARS-CoV-2 Entry by Using Human ACE2. Cell 2020, 181, 894-904. [CrossRef]

89. Hoffmann, M.; Kleine-Weber, H.; Schroeder, S.; Kruger, N.; Herrler, T.; Erichsen, S.; Schiergens, T.S.; Herrler, G.; Wu, N.-H.; Nitsche, A.; et al. SARS-CoV-2 Cell Entry Depends on ACE2 and TMPRSS2 and Is Blocked by a Clinically Proven Protease Inhibitor. Cell 2020, 181, 271-280. [CrossRef]

90. Chen, Y.; Su, C.Y.; Ke, M.; Jin, X.; Xu, L.R.; Zhang, Z.; Wu, A.D.; Sun, Y.; Yang, Z.N.; Tien, P.; et al. Biochemical and structural insights into the mechanisms of SARS coronavirus RNA ribose 2'-O-methylation by nsp16/nsp10 protein complex. PLoS Pathog. 2011, 7, e1002294. [CrossRef]

91. Belouzard, S.; Chu, V.C.; Whittaker, G.R. Activation of the SARS coronavirus spike protein via sequential proteolytic cleavage at two distinct sites. Proc. Natl. Acad. Sci. USA 2009, 106, 5871-5876. [CrossRef] 
92. Tang, T.; Bidon, M.; Jaimes, J.A.; Whittaker, G.R.; Daniel, S. Coronavirus membrane fusion mechanism offers a potential target for antiviral development. Antivir. Res. 2020, 178, 104792. [CrossRef] [PubMed]

93. Follis, K.E.; York, J.; Nunberg, J.H. Furin cleavage of the SARS coronavirus spike glycoprotein enhances cell-cell fusion but does not affect virion entry. Virology 2006, 350, 358-369. [CrossRef]

94. Wu, F.; Zhao, S.; Yu, B.; Chen, Y.-M.; Wang, W.; Song, Z.-G.; Hu, Y.; Tao, Z.-W.; Tian, J.-H.; Pei, Y.-Y.; et al. A new coronavirus associated with human respiratory disease in China. Nature 2020, 579, 265-269. [CrossRef] [PubMed]

95. Dimitrov, D.S. The secret life of ACE2 as a receptor for the SARS virus. Cell 2003, 115, 652-653. [CrossRef]

96. Wang, W.; McKinnie, S.M.; Farhan, M.; Paul, M.; McDonald, T.; McLean, B.; Llorens-Cortes, C.; Hazra, S.; Murray, A.G.; Vederas, J.C.; et al. Angiotensin-Converting Enzyme 2 Metabolizes and Partially Inactivates Pyr-Apelin-13 and Apelin-17. Hypertension 2016, 68, 365-377. [CrossRef]

97. Zhao, P.; Praissman, J.L.; Grant, O.C.; Cai, Y.; Xiao, T.; Rosenbalm, K.E.; Aoki, K.; Kellman, B.P.; Bridger, R.; Barouch, D.H.; et al. Virus-Receptor Interactions of Glycosylated SARS-CoV-2 Spike and Human ACE2 Receptor. Cell Host Microbe 2020. [CrossRef] [PubMed]

98. Li, F.; Li, W.; Farzan, M.; Harrison, S.C. Structural biology: Structure of SARS coronavirus spike receptor-binding domain complexed with receptor. Science 2005, 309, 1864-1868. [CrossRef]

99. Jiang, L.; Xiong, Z.; Song, Y.; Lu, Y.; Chen, Y.; Schultz, J.S.; Li, J.; Liao, J. Protein-Protein Affinity Determination by Quantitative FRET Quenching. Sci. Rep. 2019, 9, 2050. [CrossRef]

100. Witkowska, D.; Rowinska-Zyrek, M. Biophysical approaches for the study of metal-protein interactions. J. Inorg. Biochem. 2019, 199, 110783. [CrossRef]

101. Bhalla, N.; Pan, Y.; Yang, Z.; Payam, A.F. Opportunities and Challenges for Biosensors and Nanoscale Analytical Tools for Pandemics: COVID-19. ACS Nano 2020, 14, 7783-7807. [CrossRef]

102. Witkowska, D.; Cox, H.L.; Hall, T.C.; Wildsmith, G.C.; Machin, D.C.; Webb, M.E. Analysis of substrate binding in individual active sites of bifunctional human ATIC. Biochim. Et Biophys. Acta Proteins Proteom. 2018, 1866, 254-263. [CrossRef]

103. Pierce, M.M.; Raman, C.S.; Nall, B.T. Isothermal titration calorimetry of protein-protein interactions. Methods A Companion Methods Enzymol. 1999, 19, 213-221. [CrossRef] [PubMed]

104. Salvatori, G.; Luberto, L.; Maffei, M.; Aurisicchio, L.; Roscilli, G.; Palombo, F.; Marra, E. SARS-CoV-2 SPIKE PROTEIN: An optimal immunological target for vaccines. J. Transl. Med. 2020, 18, 222. [CrossRef] [PubMed]

105. Zhao, H.; Boyd, L.F.; Schuck, P. Measuring protein interactions by optical biosensors. Curr. Protoc. Protein Sci. 2017, 88, 20.2.1-20.2.25. [CrossRef]

106. Hilgenfeld, R. From SARS to MERS: Crystallographic studies on coronaviral proteases enable antiviral drug design. FEBS J. 2014, 281, 4085-4096. [CrossRef] [PubMed]

107. Zhou, Y.; Hou, Y.; Shen, J.; Huang, Y.; Martin, W.; Cheng, F. Network-based drug repurposing for novel coronavirus 2019-nCoV/SARS-CoV-2. Cell Discov. 2020, 6, 14. [CrossRef] [PubMed]

108. Tai, W.B.; He, L.; Zhang, X.J.; Pu, J.; Voronin, D.; Jiang, S.B.; Zhou, Y.S.; Du, L.Y. Characterization of the receptor-binding domain (RBD) of 2019 novel coronavirus: Implication for development of RBD protein as a viral attachment inhibitor and vaccine. Cell. Mol. Immunol. 2020, 17, 613-620. [CrossRef]

109. Guo, Y.-R.; Cao, Q.-D.; Hong, Z.-S.; Tan, Y.-Y.; Chen, S.-D.; Jin, H.-J.; Tan, K.-S.; Wang, D.-Y.; Yan, Y. The origin, transmission and clinical therapies on coronavirus disease 2019 (COVID-19) outbreak-an update on the status. Mil. Med Res. 2020, 7, 11. [CrossRef]

110. Available online: https://covid19.who.int/ (accessed on 31 August 2020).

(C) 2020 by the author. Licensee MDPI, Basel, Switzerland. This article is an open access article distributed under the terms and conditions of the Creative Commons Attribution (CC BY) license (http://creativecommons.org/licenses/by/4.0/). 